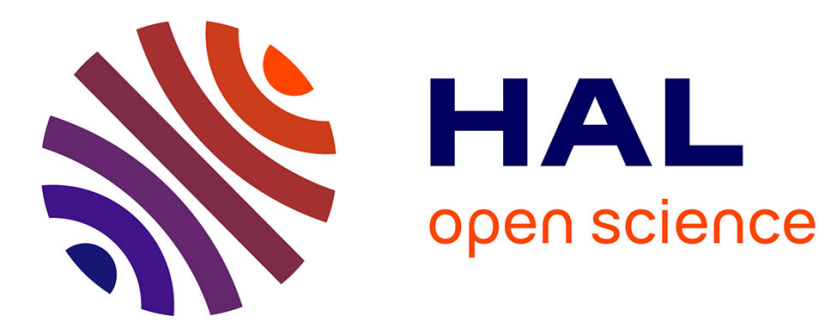

\title{
Modelling wetland habitats for species management: the case of teal (Anas crecca crecca) in the Bassin d'Arcachon (French Atlantic Coast)
}

Michel M. Génard, Francoise F. Lescourret

\section{- To cite this version:}

Michel M. Génard, Francoise F. Lescourret. Modelling wetland habitats for species management: the case of teal (Anas crecca crecca) in the Bassin d'Arcachon (French Atlantic Coast). Journal of Environmental Management, 1992, 34, pp.179-195. hal-02709252

HAL Id: hal-02709252

https://hal.inrae.fr/hal-02709252

Submitted on 1 Jun 2020

HAL is a multi-disciplinary open access archive for the deposit and dissemination of scientific research documents, whether they are published or not. The documents may come from teaching and research institutions in France or abroad, or from public or private research centers.
L'archive ouverte pluridisciplinaire HAL, est destinée au dépôt et à la diffusion de documents scientifiques de niveau recherche, publiés ou non, émanant des établissements d'enseignement et de recherche français ou étrangers, des laboratoires publics ou privés. 


\title{
Modelling Wetland Habitats for Species Management: the Case of Teal (Anas crecca crecca) in the Bassin d'Arcachon (French Atlantic Coast)
}

\author{
Michel Genard* and Françoise Lescourret† \\ Groupe d'Etude et de Recherche en Ecologie Appliquée, Université de Bordeaux I, \\ Avenue des Facultés, F-33405 Talence, Cédex, France
}

Received 10 September 1990

\begin{abstract}
Sampling points in the Bassin d'Arcachon described by habitat variables, occupied or unoccupied by teal, were compared by means of discriminant barycentric analysis in order to forecast probabilities of occurrence of teal on the basis of habitat measures. A preliminary model involving many variables was established. It was used to predict the area likely to be occupied by teal in a hunted area in the event of protection from hunting. A final model was proposed involving a reduced number of variables. This model provides a diagnosis of the potential suitability of a sampling point and gives advice on improving it.
\end{abstract}

Keywords: Teal (Anas crecca crecca), Bassin d'Arcachon, habitat model, multivariate analysis.

\section{Introduction}

Wetlands are amongst the most endangered natural habitats (Bellrose and Low, 1978; Fog and Lampio, 1982; Lefeuvre, 1986). Many have been drained for intensive agriculture while others have remained as pasture, but are no longer grazed as this practice is declining (Tesson, 1988). Such areas rapidly become unsuitable for wildfowl.

Managers of wetland areas need to have available a set of management guidelines and the tools with which to apply them. In this respect, modelling of the habitat can help wetland management.

Habitats, in a large sense, contain not only landscape physiognomy and vegetation, but also food supplies, competitors and predators, and agents that can cause disturbance (Karr, 1980; Schamberger and O'Neil, 1986). Operational habitat models, however, must be limited to variables that are easy to measure (Schamberger and O'Neil, 1986; Mosher et al., 1986). Habitats are often described only in terms of landscape and vegetation (Clawson et al., 1984; Morrison, 1987; Straw et al., 1986). Such operational

\footnotetext{
*Present address: INRA, CRA d'Avignon, Station d'Agronomie, Domaine Saint Paul, BP 91, F-84140 Montfavet, France.

$\nmid$ Present address: INRA, CRZV de Theix, Laboratoire d'Ecopathologie, F-63122 Ceyrat, France.
} 
models exist, called "habitat suitability index" models, which are based on a narrow definition of habitat and carrying capacity (Schamberger and O'Neil, 1986), providing a bridge between the fields of planning and science. Although most of them have been developed on the basis of general statements and literature reviews about species' habitat preferences, and verified by an authority, some of them use a data-based approach (Brennan et al., 1986).

The aim of this paper is to propose such a habitat model, capable of indicating suitable roosting areas for teal (Anas crecca crecca) wintering in a large basin of the French Atlantic coast, the Bassin d'Arcachon. The stages of its conception are: (i) defining the habitats used by teal in the study area; (ii) modelling the potential suitability of a given area and applying the model to an exemplary case; and (iii) simplifying the model and making it capable of indicating how a given area should be improved for teal.

\section{Study area}

The study areas were situated on the French Atlantic coast, in the Bassin d'Arcachon $\left(44^{\circ} 40^{\prime} \mathrm{N}, 1^{\circ} 4^{\prime} \mathrm{W}\right)$. The Bassin d'Arcachon is on an important wildfowl migration axis (Boutet, 1980; Yesou et al., 1983). It is frequented by numerous ducks (Davant et al., 1975 ) and is a wetland of international importance according to the criteria in Scott (1980). Its climate is oceanic.

The study areas consisted of 1020 ha of marshes distributed in three sets (Figure 1). They were man-made during the 18th century and are continually subject to filling and afforestation (Coutarel and Larché, 1986). Sixty per cent of the area is covered by brackish ponds, half devoted to extensive fish breeding and half abandoned. The ponds are 0.2 to $0.6 \mathrm{~m}$ deep and served by ditches 0.8 to $1.5 \mathrm{~m}$ deep (Labourg, 1980). The banks of the ponds are covered by grasses, bushes and trees. Wet grasslands (with scattered pools) overgrown with woody vegetation and reeds (Phragmites communis) occupy the parts of the study areas between ponds.

The areas frequented by teal were known from monthly surveys conducted since 1972-1973 (A. Fleury, pers. comm.; Génard and Bouteiller, 1988). They did not change from one year to another. Teal overwintered entirely within no-shooting areas (425 ha), occupying 51 ha $(12 \%)$. The teal wintering in the Bassin d'Arcachon comprise 0.15 to $0 \cdot 6 \%$ of the 200000 teal wintering in western Europe (see Rüger et al., 1986). Their numbers vary considerably from one year to another (Figure 2).

\section{Methods}

\subsection{STUDY DESIGN}

Presence-absence of teal was considered. Three sets of sampling points were used. Two (A, B) were in areas protected from hunting and other human disturbance. A and B constituted the modelled area, covering the 425 ha referred to above. A covered parts of study areas entirely occupied by teal, whereas B covered parts not occupied. The third set, $\mathrm{C}$, covering a slightly larger part than $\mathrm{A}$ and $\mathrm{B}$ combined, was subject to hunting. The habitat variables characterizing the reserve were compared between the parts occupied by teal (A) and the parts not occupied (B) in order to define suitable teal habitat. A habitat model was then established. It was used to forecast the potential suitability of the area actually hunted $(C)$ in the event of it being protected from hunting. The initial model was then simplified to make it operational. Finally, we explored the capacity of the model to suggest changes that would improve an area for teal. 


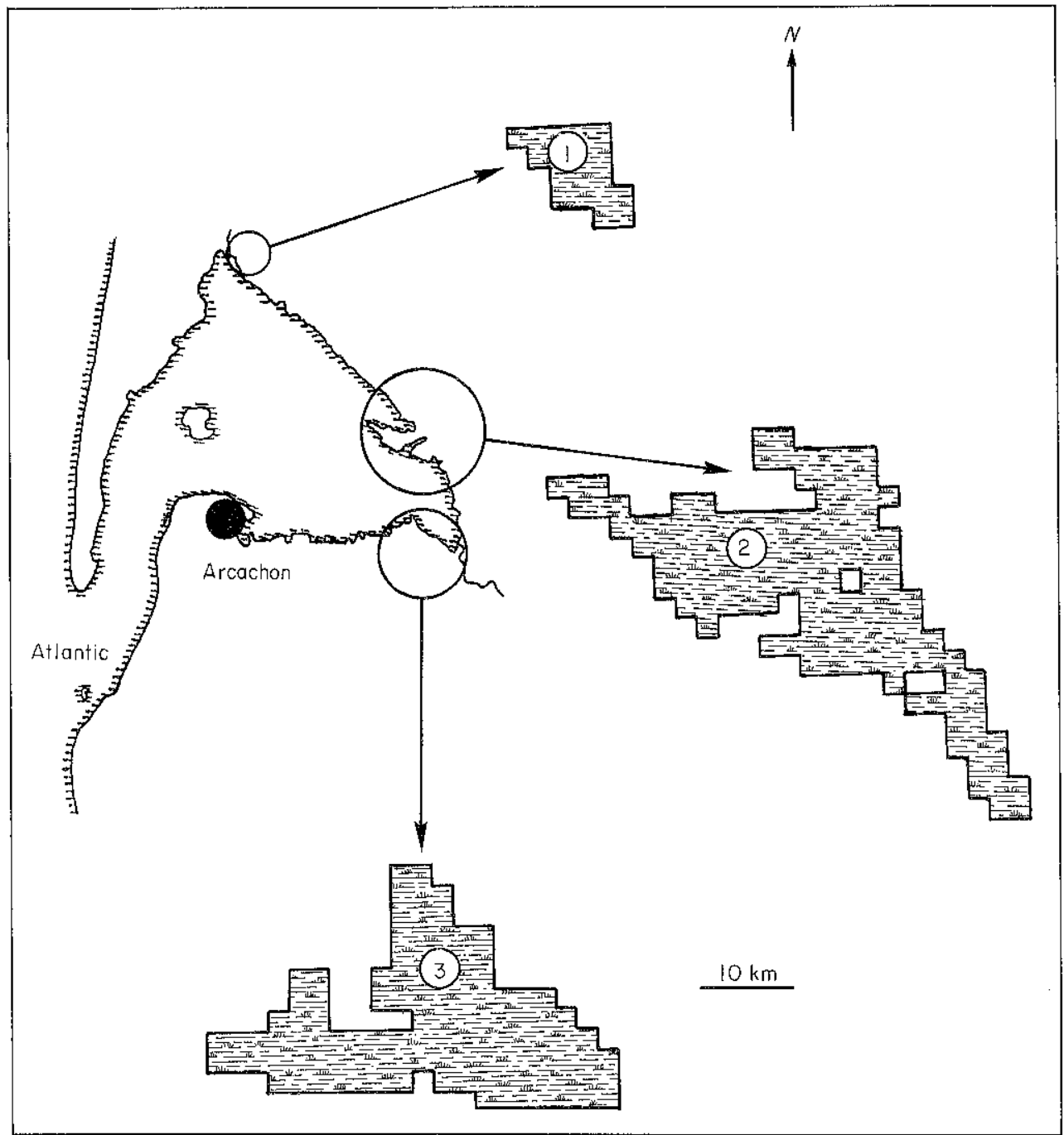

Figure 1, Location of the three sets of marshes.

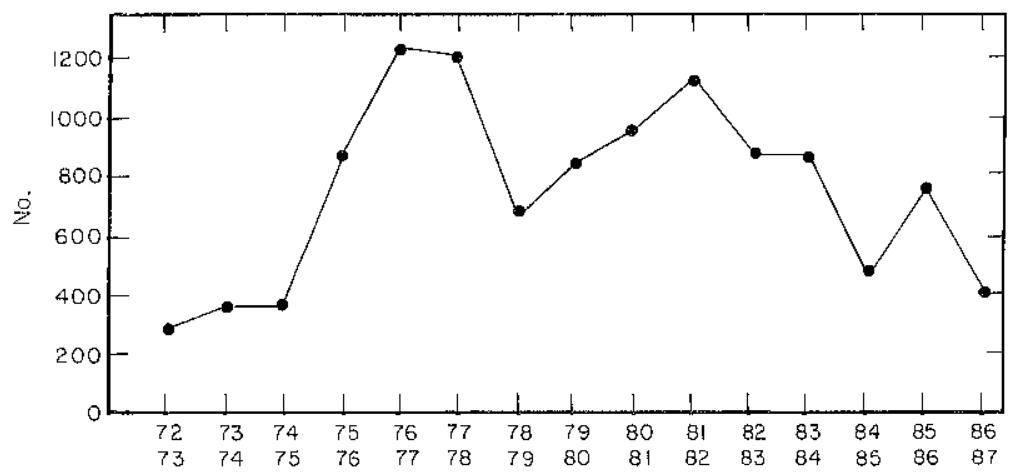

Figure 2. Mean numbers of teal (calculated from four monthly surveys-November to February) wintering in the Bassin d'Arcachon from 1972-1973 to 1986-1987. (After Fleury 1974, 1975, 1977a, 1977b, 1980; Callec, 1983; GEREA, unpublished). 


\subsection{SAMPLING}

Habitat variables were surveyed during the winter 1986-1987 and 1987-1988. Using variables measured at a particular time was relevant because of little change in distribution patterns from one year to another (see above).

Sampling involved a total of 85 sampling points for A, 94 for B and 147 for C. Sampling points were distributed on grids, $60 \times 60 \mathrm{~m}$ in parts occupied by teal and $200 \times 200 \mathrm{~m}$ elsewhere in the study area. The area covered by A being smaller than that covered by $\mathrm{B}$ or $\mathrm{C}$, the sampling effort was adapted to area by changing the size of sampling grids to obtain similar number of points with and without teal. Such a similarity was required by the modelling technique. A further set of 30 sampling points distributed in parts occupied or unoccupied by teal were collected apart from A, B or C to test the models.

\subsection{HABITAT VARIABLES}

The use of an area by teal depends on such features as biotope, bank type, water salinity and surface area, and openness of the site (Tamisier, 1974; Saint-Gérand, 1985). On the basis of a preliminary study (Génard and Fleury, in press), we chose 20 variables of this type, uncorrelated to satisfy statistical conditions. At each sampling point, the percentage covered by the following variables measured in a $30 \mathrm{~m}$ radius around the observer was:

(a) water $<0.2 \mathrm{~m}$ deep (D1), 0.2-0.4 $\mathrm{m}$ deep (D2), $>0.4 \mathrm{~m}$ deep (D3);

(b) mud or gravel (MU);

(c) vegetation, including reed beds (RE), flooded rushes (Juncus sp.) (FR), dry rushes (DR), grasslands $<0.25 \mathrm{~m}$ high (LG), grasslands $>0.25 \mathrm{~m}$ high $(\mathrm{HG})$, bushes (B), trees $(\mathrm{T})$.

Per cent cover was estimated by comparison with reference drawings representing hypothetical covers of $5 \%, 10 \%, \ldots, 90 \%$ (Prodon, 1976). Also measured were:

(a) per cent of bank length of shallow sloping banks (B1), medium sloping banks (B2), moderately steep sloping banks (B3), steep sloping banks (B4) (see Appendix 1);

(b) area of the pond ("wet" area WA) and of rushes (rush area=RA) within the sampled circle;

(c) mean salinity (MS), distributed in three classes (8\%, $12 \%, 18 \%$ ) from a map of the Bassin d'Arcachon (Labourg, 1969);

(d) site openness in terms of length of field of view (FW) and angle of view (AV) (see Appendix 1).

\subsection{HABITAT DEFINITION AND CONSTRUCTION OF THE MODEL}

Our design used multivariate analysis, which is well adapted to habitat studies (Shugart, 1981). A discriminant analysis (Legendre and Legendre, 1979) was not employed despite its wide application in such studies (Johnson, 1981), particularly for duck habitats (Krasowski and Nudds, 1986). Discriminant analysis requires quantitative variables and equality of group variance-covariance matrices. It is not suitable for data with numerous zero scores, and it describes only linear relationships. Multinormality is 
required in some applications. Such conditions are rarely encountered in habitat studies (Anderson, 1981; Edge et al., 1987; Johnson, 1981; Williams, 1981; Best and Stauffer, 1986). An alternative approach would have been that of logistic regression, which is applied to habitat studies (Straw et al., 1986), but we preferred a weighted averaging method. Ter Braak and Looman (1986) have shown that logistic regression is more efficient than weighted averaging techniques when the probability of occurrence of a species is modelled as a Gaussian response to a quantitative environmental gradient, but weighted averaging techniques are simpler and are approximations to the Gaussian methods, giving good estimates of the species' optima and environmental values (Ter Braak and Prentice, 1988).

We therefore used a discriminant barycentric analysis (DBA) (Benzecri, 1977; Bergougnan and Couraud, 1982; Kouadi, 1984). DBA performs a correspondence analysis (CA) of a two-row table, rows being sums of lines of groups being compared (see Greenacre, 1984, for using CA for discrimination purposes). As CA can deal with qualitative variables (Chessel and Debouzie, 1983), we were able to use 67 modalities instead of 20 original variables (Appendix 2), and non-linear relationships could be considered. The DBA was run on sets $\mathrm{A}$ and $\mathrm{B}$. It was performed on a two-row table weighted to render both numbers of sampling points ( 85 for A, 94 for B) equal (see Bergougnan and Couraud, 1982). The original 179 sampling points were projected on the unique axis by the eigenvector values. The quality of discrimination was estimated from the percentage of points classified in their original groups (place of the projection on the axis with respect to the discriminant plane) and to results obtained on the test sample (30 points: see Section 32).

Discriminant variables were those with high (> mean) absolute contributions (= part of variance of the unique component explained by the variable). Axis scores were indices related to the potential suitability of sampling points (Rice et al., 1986). The discriminant axis was divided into $i$ intervals as recommended by Kouadi (1984). The probability of occurrence of teal in each sampling point of $i$ was:

$$
P_{i}=A_{i} \mathrm{FNB} /\left(A_{i} \mathrm{FNB}+(1-F) \mathrm{NA}\right)
$$

where: $A_{t}$ is the ratio of points with teal/points without teal in $i ; F$ is the mean probability of occurrence of teal in a sampling point of the modelled area, i.e. the frequency of occurrence of teal in the A+B area (see study area); NA the number of A pointsnumber of points in area occupied by teal-and NB the number of $B$ points - number of points in area not occupied by teal (calculation demonstrated in Appendix 3). The classification criterion (projection of points on the axis due to the eigenvectors values) was used to forecast the probability of occurrence of teal in the set $\mathrm{C}$ in the event of protection from hunting.

\subsection{CONSTRUCTION OF AN OPERATIONAL MODEL FOR MANAGEMENT PURPOSES}

The analysis was repeated with only the contributing variables to minimize the number of variables requiring measurement in the field and thereby to limit costs. The quality of results was judged by comparing the discriminant point scores of the "complete" and the "partial" analyses.

In order to define suitable improvements to habitats where the probability of occurrence of teal was weak, we built a set of rules to be realized in a suitable area. By considering two types of modalities: the first one, with a majority of 1 values in sampling points having $P_{i}=1$, was likely to favour the occurrence of teal; the second one, with a 
majority of 0 values in sampling points having $P_{i}=1$, was likely to favour the nonoccurrence of teal. The relevance of the rules was tested on a sample of points diagnosed as unsuitable for teal after simulating recommended changes.

\section{Results}

\subsection{DESCRIBING AND MODELLING DIURNAL HABITATS OF TEAL IN THE BASSIN D'ARCACHON}

The discriminant axis clearly separated the sampling points with teal from sampling points without teal (Figure 3): $84 \%$ of 85 sampling points with teal and $85 \%$ of 94 sampling points without teal were correctly classified ( $=$ allocated to their original groups). Eighty seven per cent of the test sample points were also correctly classified.

Modalities of 10 variables among the 20 contributed to the unique axis (Figure 4). They defined habitats with teal as those containing $0 \cdot 20-0.40 \mathrm{~m}$ deep ponds and flooded rushes with a cover of $25-100 \%$; shallow or medium sloping banks were dominant; the environment was open (a wide angle of view); salinity was about $12 \%$. In contrast, sampling points without teal were covered by low grassland; water basins were rare and, where present, they had moderately steep sloping banks and a high salinity. The environment was closed (a small angle of view).

Sampling points were distributed in four groups according to their axis scores (Figure 3). The first group (scores $<=-1$ ) corresponded to a constant presence of teal, and the fourth (scores $>1$ ) corresponded to a constant absence of teal, groups two and three (intervals $]-1,0]$ and $] 0,+1]$ ) being intermediate. The probability of occurrence of teal was estimated for the four groups (Table 1).

Sampling points in the 592 hunted area (C) were distributed amongst the four groups by the classification criterion generated by the discriminant analysis (Table 2). Half of

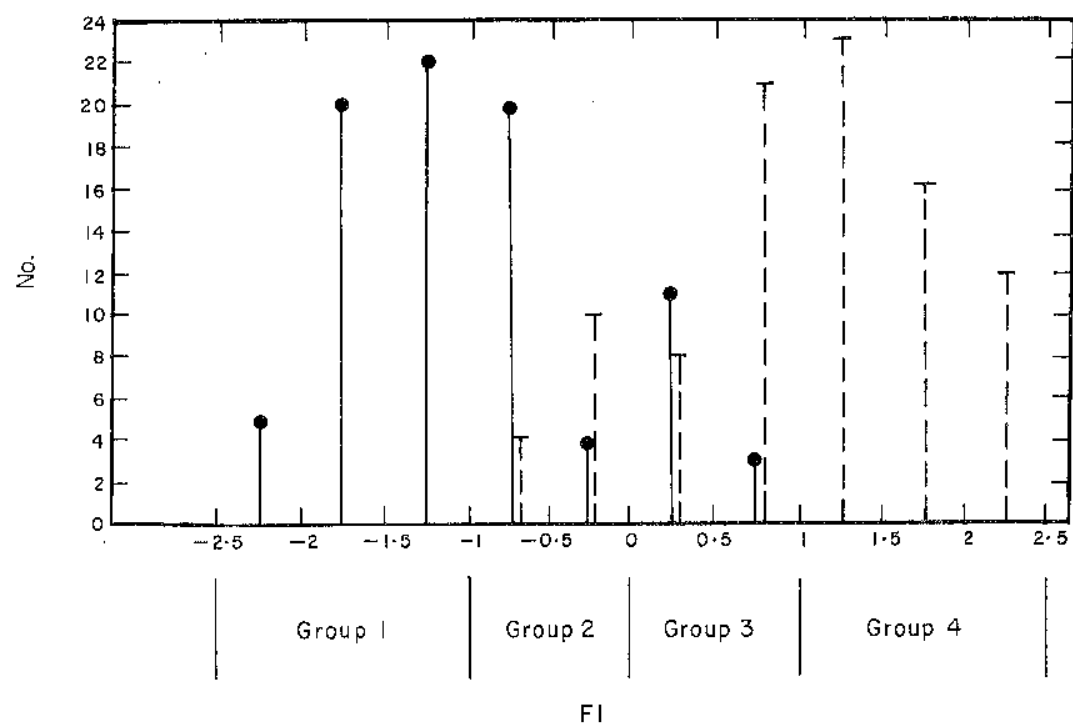

Figure 3. Number of sampling points with teal (full lines) and without teal (dotted lines) distributed in four groups according to their discriminant axis $\mathrm{Fl}$ scores (complete analysis, 20 variables). 


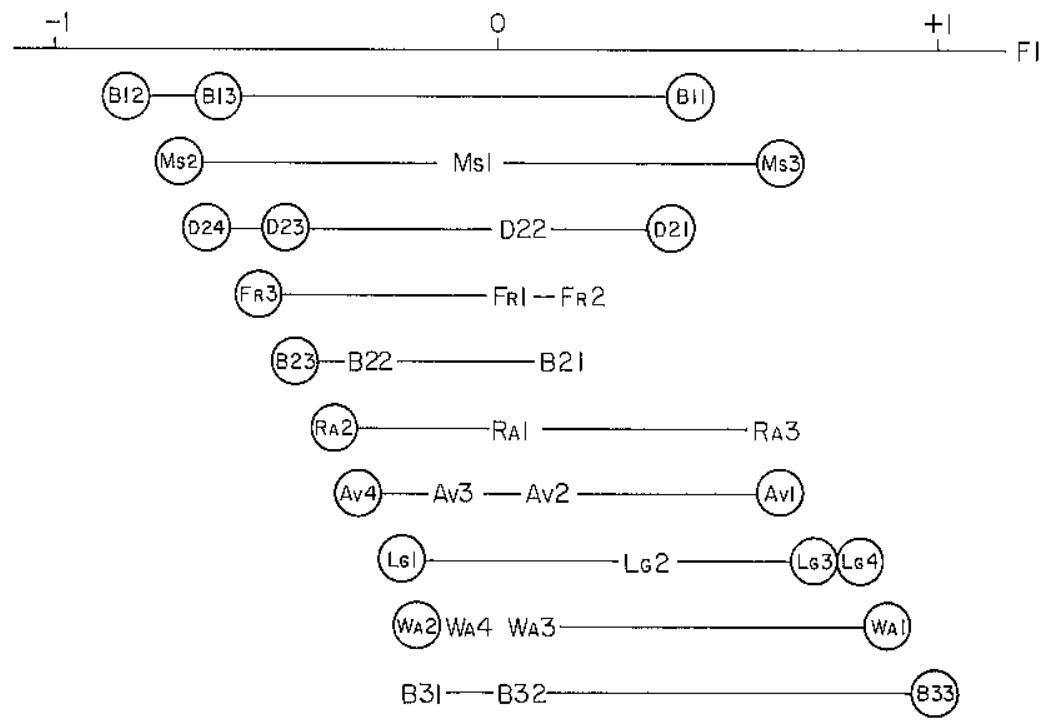

Figure 4. F1 axis scores of the modalities of the variables with high absolute contributions in the complete analysis (ringed modalities have high absolute contributions).

TABLE 1. A $i$ values and probabilities $P_{i}$ of occurrence of teal estimated in four groups of sampling points according to their axis scores after the complete or the partial discriminant barycentric analysis $\mathrm{Da}$

\begin{tabular}{|c|c|c|c|c|c|}
\hline \multirow[b]{2}{*}{ Group } & \multirow[b]{2}{*}{ Da score } & \multicolumn{2}{|r|}{$\mathrm{A} i$} & \multicolumn{2}{|r|}{$P_{i}$} \\
\hline & & Compl. & Part. & Compl. & Part. \\
\hline 1 & $<=-1$ & $+\infty$ & $+\infty$ & 1 & 1 \\
\hline 2 & ]$-1,0]$ & 1.9 & $2 \cdot 8$ & 0.2 & $0 \cdot 28$ \\
\hline 3 & ] $0,1]$ & 0.5 & 0.4 & 0.07 & 0.05 \\
\hline 4 & $>1$ & 0 & 0 & 0 & 0 \\
\hline
\end{tabular}

TABLE 2. Distribution of the hunted area sampling points amongst the four groups defined by the discriminant barycentric analysis

\begin{tabular}{lcccc}
\hline Group & $\begin{array}{c}\text { Probability of } \\
\text { occurrence of teal }\end{array}$ & $\begin{array}{c}\text { Number of points } \\
(\%)\end{array}$ & $\begin{array}{c}\text { Area } \\
\text { (ha) }\end{array}$ & $\begin{array}{c}\text { Area likely to be } \\
\text { occupied by teal (ha) }\end{array}$ \\
\hline 1 & 1 & 3 & 12 & 12 \\
2 & 0.21 & $(2)$ & 95 & 20 \\
3 & 0.07 & $(16)$ & 207 & 14 \\
4 & 0 & $(35)$ & 278 & 0 \\
\hline
\end{tabular}


area $\mathrm{C}$ appeared to be unsuitable for teal. A ban on hunting in the parts of area $\mathrm{C}$ classified into groups 1,2 and 3 (Table 2) would render 40 to 50 ha suitable for teal, which would double the actual area of suitable habitat.

\subsection{SIMPLIFIED MODEL FOR ESTIMATING POTENTIAL OCCURRENCE OF TEAL}

Eighty-seven per cent of the sampling points were correctly classified by the partial DBA (10 variables) classification criterion. The same proportion of the test sample points was correctly classified. The axis scores for the partial and complete models were highly correlated $(r=0.974, P<0.005)$, indicating that similar information was obtained in both.

Moreover, the distribution of sampling points with and without teal was identical on each axis (Figure 5). This result led us to use the classification criterion of the simplified model (Table 3) for forecasting the occurrence of teal. As before, the axis was divided into four groups in each of which the probability of occurrence of teal was estimated (Table 1).

\subsection{OPERATIONAL MODEL FOR MANAGEMENT PURPOSES}

The six variables with high absolute contributions to the unique axis of the partial analysis were retained (D2, LG, B1, B3, AV and MS-see Appendix 2 for descriptions). Five, among their modalities (LG3, LG4, B33, AV1, MS3), had null values in each unit of the group of sampling points of habitats suitable for teal $\left(P_{i}=1\right)$. No such modality should occur in points revealing suitable habitat for teal. Five other modalities (D24, LG1, B12, B13, MS2) had a majority of 1 values in the group of sampling points of habitats suitable for teal. The sampling points of this group had an average of 2-3 such

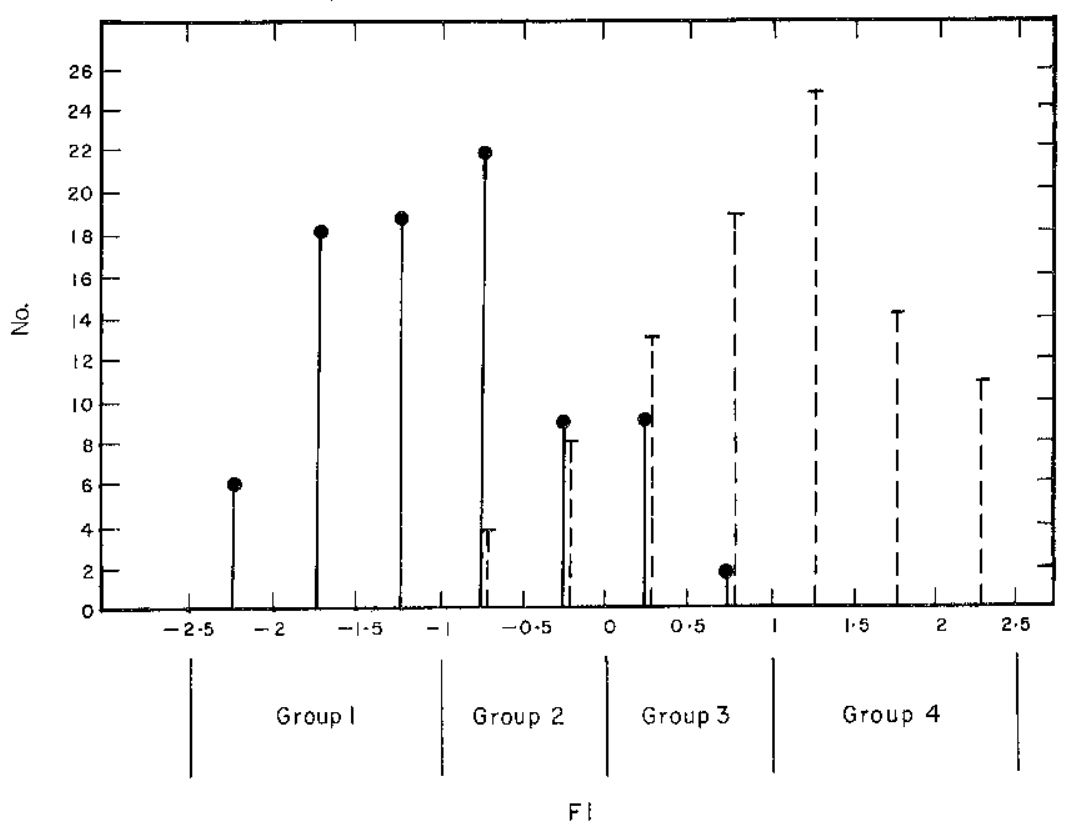

Figure 5. Number of sampling points with teal (full lines) and without teal (dotted lines) distributed in four groups according to their discriminant axis F1 scores (partial analysis, 10 variables). 
TABLE 3. Coefficients for modalities of variables in the linear equation of the axis of the partial discriminant barycentric analysis modalities with positive coefficients show absence of teal, modalities with negative coefficients show presence.

\begin{tabular}{|c|c|c|}
\hline & Modality & Coefficient \\
\hline Water $0 \cdot 2-0 \cdot 4 \mathrm{~m}$ deep (per cent cover) & $\begin{array}{l}\text { D21: } 0 \\
\text { D22: } 0-25 \\
\text { D23: } 25-50 \\
\text { D24: } 50-100\end{array}$ & $\begin{array}{l}+0.28 \\
+0.01 \\
-0.34 \\
-0.44\end{array}$ \\
\hline Flooded rushes (per cent cover) & $\begin{array}{l}\text { FR2: } 0-25 \\
\text { FR1: } 0 \\
\text { FR3: } 25-100\end{array}$ & $\begin{array}{l}+0.12 \\
+0.03 \\
-0.37\end{array}$ \\
\hline Grasslands $<0.25 \mathrm{~m}$ high (per cent cover) & $\begin{array}{l}\text { LG3: } 25-50 \\
\text { LG4: } 50-100 \\
\text { LG2: } 0-25 \\
\text { LG1: } 0\end{array}$ & $\begin{array}{l}+0.52 \\
+0.48 \\
+0.23 \\
-0.19\end{array}$ \\
\hline Shallow sloping banks (per cent of bank length) & $\begin{array}{l}\text { B11: } 0 \\
\text { B13: } 50-100 \\
\text { B12: } 0-50\end{array}$ & $\begin{array}{l}+0.32 \\
-0.43 \\
-0.55\end{array}$ \\
\hline Medium sloping banks (per cent of bank length) & $\begin{array}{l}\text { B21: } 0 \\
\text { B22: } 0-50 \\
\text { B23: } 50-100\end{array}$ & $\begin{array}{l}+0.09 \\
-0.20 \\
-0.30\end{array}$ \\
\hline Moderately steep sloping banks (per cent of bank length) & $\begin{array}{l}\text { B33: } 50-100 \\
\text { B32: } 0-50 \\
\text { B31: } 0\end{array}$ & $\begin{array}{l}+0.66 \\
+0.06 \\
-0.09\end{array}$ \\
\hline Area of the pond (ha) & $\begin{array}{l}\text { WA1: } 0 \\
\text { WA3: } 0-10 \\
\text { WA4: }>10 \\
\text { WA2: } 0-2\end{array}$ & $\begin{array}{l}+0.60 \\
+0.03 \\
-0.09 \\
-0.19\end{array}$ \\
\hline Area of flooded rushes (ha) & $\begin{array}{l}\text { RA3: }>0.5 \\
\text { RA1: } 0 \\
\text { RA2: } 0-0.5\end{array}$ & $\begin{array}{l}+0.45 \\
+0.05 \\
-0.27\end{array}$ \\
\hline Angle of view( $\left(^{\circ}\right)$ & $\begin{array}{l}\text { AV1: }<3 \\
\text { AV2: 3-15 } \\
\text { AV3: } 15-45 \\
\text { AV4: }>45\end{array}$ & $\begin{array}{l}+0.41 \\
+0.10 \\
-0.08 \\
-0.22\end{array}$ \\
\hline Mean salinity (\%) & $\begin{array}{l}\text { MS3: } 18 \\
\text { MS1: } 8 \\
\text { MS2: } 12\end{array}$ & $\begin{array}{l}+0.43 \\
-0.05 \\
-0.52\end{array}$ \\
\hline
\end{tabular}

modalities, $96 \%$ of them having at least two. In contrast, $99 \%$ of points of habitats unsuitable for teals $\left(P_{i}=0\right)$ had less than two such modalities: other situations $\left(P_{i}=0.05\right.$ or 0.28 ) were intermediate (Table 4 ). It was therefore judged sufficient to take into account the occurrence of any two of these modalities. Two other modalities (D21 and B11) had a majority of 0 values in the group of the points of habitats suitable for teal. The points of this group had at most one such modality, whereas $88 \%$ of the points of 
habitats unsuitable for teal had both of these modalities (Table 5). We therefore suggest that a suitable area should contain at most either one of these two modalities.

The advice rules are formally: (i) percentage cover of $25-50 \%$ of grasslands $<0.25 \mathrm{~m}$ high, (LG3) = percentage cover of $50-100 \%$ of grasslands $<0.25 \mathrm{~m} \mathrm{high,} \mathrm{(LG4)}=$ percentage of bank length 50-100\% with moderately steep sloping banks, (B33) $=$ angle of view $<3^{\circ}(\mathrm{AV} 1)=$ mean salinity of $18 \%$ (MS3) $=0$; (ii) percentage cover of $50-100 \%$ of water $0.2-0.4 \mathrm{~m}$ deep (D24) + percentage cover of $0 \%$ of grasslands $<0.25 \mathrm{~m}$ high (LG1) + percentage of bank length $0-50 \%$ with shallow sloping banks (B12) + percentage of bank length $50-100 \%$ with shallow sloping banks (B13) + mean salinity of $12 \%$ (MS2) $>=2$; and (iii) percentage cover of $0 \%$ of water $0.2-0.4 \mathrm{~m}$ deep (D21) + percentage of bank length $0 \%$ with shallow sloping banks $(\mathrm{B} 11)<=1$.

An area suitable for teal should follow these rules, and was verified in $96 \%$ of the sampling points. Conversely, an area unsuitable for teal $\left(P_{i}=0\right.$ or 0.05$)$ should not follow the three rules simultaneously, which was verified in $99.5 \%$ of sampling points. Points with $P_{i}=0.28$ were intermediate, $15 \%$ of them following the three rules.

The relevance of these rules was tested in a simulation of 67 points with an initial $P_{i}=0$. After following the suggested course of action, their potentialities were improved to $P_{i}=0 \cdot 28$ for 33 points and $P_{i}=1$ for the other 34 .

The rules for estimating potential occurrence of teal after measuring 10 variables in an area (simplified model), and for suggesting changes that would improve this area, were written into a computer program suitable for use by managers. The program is available from the authors.

TABLE 4. Frequency of occurrence of $0,1,2,3$ or 4 modalities among D24, LG1, B12, B13, MS2 (\%), and confidence interval (CI) of the mean number of occurrences of these five modalities, at four levels of probability for occurrence of teal

\begin{tabular}{|c|c|c|c|c|c|c|c|}
\hline \multirow[b]{2}{*}{$\begin{array}{l}\text { Probability of } \\
\text { occurrence of teal }\end{array}$} & \multicolumn{5}{|c|}{ Number of modalities } & \multirow[b]{2}{*}{ CI $(P=0.05)$} & \multirow[b]{2}{*}{$\begin{array}{l}\text { Number of } \\
\text { points }\end{array}$} \\
\hline & 0 & 1 & 2 & 3 & 4 & & \\
\hline 1 & 0 & 4 & 30 & 44 & 22 & $2 \cdot 61-3.07$ & 50 \\
\hline 0.28 & 3 & 32 & 58 & 7 & 0 & $1.52-1.68$ & 62 \\
\hline 0.05 & 25 & 55 & 20 & 0 & 0 & $0.83-1.09$ & 94 \\
\hline 0 & 61 & 38 & 1 & 0 & 0 & $0.31-0.49$ & 120 \\
\hline
\end{tabular}

TABLE 5. Frequency of occurrence of 0,1 or 2 modalities among D21, B11 (\%) and confidence interval (CI) of the mean number of occurrences of these 2 modalities, at four levels of probability for occurrence of teal

\begin{tabular}{lrrrrr}
\hline & \multicolumn{3}{c}{ Number of modalities } & & \\
\cline { 2 - 4 } $\begin{array}{l}\text { Probability of } \\
\text { occurrence of teal }\end{array}$ & 0 & 1 & 2 & CI $(P=0 \cdot 05)$ & $\begin{array}{c}\text { Number of } \\
\text { points }\end{array}$ \\
\hline 1 & 66 & 34 & 0 & $0 \cdot 21-0 \cdot 47$ & 50 \\
0.28 & 16 & 71 & 13 & $0 \cdot 83-1 \cdot 10$ & 62 \\
0.05 & 3 & 49 & 48 & $1 \cdot 33-1 \cdot 56$ & 94 \\
0 & 0 & 12 & 88 & $1 \cdot 83-1 \cdot 94$ & 120 \\
\hline
\end{tabular}




\section{Discussion and conclusion}

The environmental characteristics sought by the teal in the Bassin d'Arcachon are the same as those generally found in wintering zones situated in coastal marshlands. They are vast open spaces where gorse, shallow and slightly salty stretches of water with gently sloping banks dominate (Tamisier, 1972; Cramp and Simmons, 1977; Saint-Gérand, 1985). This similarity confirms the validity of our model and makes it possible to envisage an application in other coastal marshlands. However, as opposed to Mosher et al. (1986), who recommended that a model should be able to be used in the greatest part of a species' natural distribution area, we believe that generalizing a model such as ours should be done only in environments similar to that for which it was developed and its validity should be proven in each new geographic situation. This is all the more necessary as the multivariate techniques used are essentially correlational and do not necessarily prove cause and effect relationships. More generally, we agree with Legay and Debouzie (1985) and Maurer (1986) who think that no two populations are identical, even within the same species. This is particularly true for the teal, whose plasticity allows it to winter in environments as varied as continental ponds and maritime basins (Cramp and Simmons, 1977).

The major interest of our model lies in the simplicity of its methodological design, which can be applied to other regions and species. The philosophy of our work can be summed up by Grubb's (1988) remark: "Unfortunately, the more sophisticated models become, the less they tend to be used by, or available to, most field biologists".

The deliberate simplicity of our methodology nevertheless has some disadvantages. The desire to create a model which could easily be used by land management workers made it impossible to take into account the potentialities of feeding grounds used at night, the minimal surface area of efficient reserves as well as some anthropic disturbances causing particular behaviours, such as the search for shelter in relatively inaccessible sectors-in some small parts of the Bassin d'Arcachon, teal seek out very closed wooded environments (Génard and Bouteiller, 1988). However, the consideration of other easily measured variables could improve our model. On the one hand, the habitat variables we considered do not describe the connecting relationships between the described site and its surroundings. It is obvious that the attractiveness of a site can depend on its isolation from other similar sites (Brown and Dinsmore, 1986) or on the characteristics of the land environment. Complimentary descriptors could be found through landscape ecology (Forman and Godron, 1986). On the other hand, the presence or absence of species other than teal in the studied environments could be considered, as competition between species can exist (Nudd, 1983).

The method we used is similar to that followed by Rice et al. (1986), whose goals were close to ours. However, in our study, the utilization of a discriminant barycentric analysis instead of a discriminant analysis used by the latter authors facilitated the distribution of our method to land managers as the application conditions for a discriminant barycentric analysis are quite broad. The discriminant barycentric analysis makes it possible to treat non-linear relationships easily, which are often problematic in modelling bird habitat relationships using traditional methods such as the multiple linear regression (Clawson et al., 1984).

Our model can be used to predict potentialities of a site unoccupied for anthropic reasons or to simulate the consequence of management on the probability of teal occurrence. A few simple rules make it possible to add indications on the management changes which should be made to improve a site. These three utilization levels are complimentary and necessary to a land manager. They should be completed by a model 
of nocturnal utilization of space in feeding grounds (see Génard, 1989). Finally, computerizing the model is well-suited to the current development of computerized tools to evaluate and improve wildlife habitats (Marcot, 1986). Putting such tools to use may represent a challenge in the near future for applied research on habitat relationships.

We are greatly indebted to the Fédération Départementale des Chasseurs de la Gironde for financial support. We are grateful to P. Doncaster, J,Y. Mondain-Monval and G. Black for their constructive comments and for improving our English.

\section{References}

Anderson, S. H. (1981). Correlating habitat variables and birds. Studies in Avian Biology 6, 538-542.

Bellrose, F. C. and Low, J. B. (1978), Advances in waterfowl management research. Wildlife Society Bulletin 6, 63-72.

Benzécri, J. P. (1977). Analyse discriminante et analyse factorielle. Les Cahiers de l'Analyse des Données 2, 369 406.

Bergougnan, D. and Couraud, C. (1982). Pratique de la discrimination barycentrique (Galets II). Les Cahiers de l'Analyse des Données 7, 341-354.

Best, L. B. and Stauffer, D. F. (1986). Factors confounding evaluation of bird-habitat relationships. In Wildlife 2000, Modeling Habitat Relationships of Terrestrial Vertebrates (J. Verner, M. L. Morrison and C. J. Ralph, eds), pp. 209-216. Wisconsin: University of Wisconsin Press.

Boutet, J. Y. (1980). L'avifaune du Bassin d'Arcachon (Gironde), potentialités d'accueil et facteurs limitants. Bulletin de l'ONC Spécial Scientifique et Technique. Paris: Office National de la Chasse, pp. 201-212.

Brennan, L. A., Block, W. M. and Gutierrez, R. J. (1986). The use of multivariate statistics for developing habitat suitability index models. In Wildlife 2000, Modeling Habitat Relationships of Terrestrial Vertebrates (J. Verner, M. L. Morrison and C. J. Ralph, eds), pp. 177-182. Wisconsin: University of Wisconsin Press.

Brown, M. and Dinsmore, J. J. (1986). Implications of marsh size and isolation for marsh bird management. Journal of Wildlife Management 50, 392-397.

Callec, A. (1983). Contribution à l'Étude de l'Hivernage de la Sarcelle d'Hiver sur le Bassin d'Arcachon. ONC Technical Report, Chanteloup.

Chessel, D. and Debouzie, D. (1983). Analyse des correspondances et écologie: causes et conséquences du succès. Actes du I2ème Colloque Méthodes Mathématiques Appliquées à la Géographie. Besançon.

Clawson, M. E., Baskett, T. S. and Armbruster, M. J. (1984). An approach to habitat modeling for herpetofauna. Wildife Society Bulletin 12, 61-69.

Coutarel, V. and Larché, R. (1986). Réhabilitation et Mise en Valeur du Delta de la Leyre. Bordeaux: Société d'Equipement de la Gironde Report.

Cramp, S. and Simmons, K. E. L. (eds) (1977). Handbook of the Birds of Europe, the Middle East and North Africa, Vol. 1. Oxford: Oxford University Press.

Davant, P., Fleury, A, and Petit, P. (1975). Le pare ornithologique du Teich. Bulletin d'Ecologie 6, $298-305$.

Edge, D. W., Marcum, C. L. and Olson-Edge, S. L. (1987). Summer habitat selection by elk in western Montana: a multivariate approach. Journal of Wildlife Management 51, 844-851.

Fleury, A. (1974). Dénombrements d'Anatidés sur les côtes et les plans d'eau aquitains en hiver 1973-74. Le Courbageot 1, 6-11.

Fleury, A. (1975). Dénombrements d'Anatidés sur les côtes et les plans d'eau aquitains en hiver 1974-75. Le Courbageot 2, 1-5.

Fleury, A. (1977a). Dénombrements d'Anatidés sur les côtes et les plans d'eau aquitains en hiver 1975-76. Le Courbageot 3, 17-20.

Fleury, A. $(1977 b)$. Dénombrements d'Anatidés hivernant sur les côtes et les plans d'eau aquitains: Hiver 1976-77. Le Courbageot 4, 20-24.

Fleury, A. (1980). Dénombrements d'Anatidés hivernant en Aquitaine: saisons 1977/78, 1978/79, 1979/80. Le Courbageot 7-8, 1-8.

Fog, J. and Lampio, T. (1982). Introduction.-When to manage. In Proceedings of the Third Technical Meeting on Western Palearctic Migratory Bird Management (D. A. Scott, ed.), pp. 12-14. Glos., U.K.: IWRB Slimbridge.

Forman, R. T. T. and Godron, M. (1986). Landscape Ecology. New York: John Wiley and Sons.

Génard, M. (1989). Etude de l'occupation de l'espace par la Sarcelle d'hiver (Anas c. crecca) au Bassin d'Arcachon, dans une perspective d'aménagement: démarche envisagée. In Quatrième Colloque de l'AFIE (Ministère de l'Environnement, ed.), pp. 331-337. Paris: Ministère de l'Environnement.

Génard, M. and Bouteiller, R. (1988). Place de deux petites remises dans l'hivernage des Sarcelles d'hiver (Anas crecca) au Bassin d'Arcachon et caractérisation des biotopes occupés. Le Gerfaut 78, 151-173. 
Greenacre, H. J. (1984). Theory and Applications of Correspondence Analysis. London: Academic Press.

Grubb, T. G. (1988). Pattern Recognition-a Simple Model for Evaluating Wildlife Habitat. Research note RM-487. Fort Collins, Colorado: USDA Forest Service, Rocky Mountain Forest and Range Experiment Station.

Johnson, D. H. (1981). The use and misuse of statistics in Wildlife habitat studies. In The Use of Multivariate Statistics in Studies of Wildlife Habitat (E. D. Capen, ed.), pp. 11-19. Fort Collins, Colorado: USDA Forest Service, Rocky Mountain Forest and Range Experiment Station.

Karr, J. R. (1980). History of the habitat concept in birds and the measurement of avian habitats. Acta XVII Congressus Internationalis Ornithologici, 991-997.

Kouadi, S. (1984). Analyse d'un facteur de risque: tabac et cancer bronchique. Les Cahiers de l'Analyse des Données 9, 447-456.

Krasowski, T. P. and Nudds, T. D. (1986). Microhabitat structure of nest sites and nesting success of diving ducks. Journal of Wildlife Management 50, 203-208.

Labourg, P. J. (1969). Contribution à l'étude écologique des réservoirs à poissons de la région d'Arcachon. Unpublished 3rd cycle thesis, University of Bordeaux I.

Labourg, P. J. (1980). Structure et évolution de la macrofaune invertébrée des écosystèmes lagunaires aménagés du Bassin d'Arcachon. Application du concept de stratégie cénotique. In Recherches d'Écologie Théorique, les Stratégies Adaptatives (R. Barbault, P. Blandin and J. A. Meyer, eds), pp. 279-295. Paris: Maloine.

Lefeuvre, J. C. (1986). Zones humides: espaces en voie de disparition? In Actes du Colloque sur les Zones Humides du Littoral Aquitain (DRAE Aquitaine and CPIE Le Teich, eds), pp. 1-27. Bordeaux: Presse Papier.

Legendre, L. and Legendre, P. (1979). Ecologie Numérique 2. La Structure des Données Écologiques. Paris: Masson.

Legay, J. M. and Debouzie, D. (1985). Introduction à Une Biologie des Populations. Paris: Masson.

Marcot, B. G. (1986). Use of expert systems in wildlife. Habitat modeling. In Wildlife 2000, Modeling Habitat Relationships of Terrestrial Vertebrates (J. Verner and C. J. Ralph, eds), pp. 145-150. Wisconsin: University of Wisconsin Press.

Maurer, B. A. (1986). Predicting habitat quality for grassland birds using density-habitat correlations. Journal of Wildlife Management 50, 556-566.

Morrison, M. L. (1987). Development and testing of linear regression models predicting bird-habitat relationships. Journal of Wildlife Management 51, 247-253.

Mosher, J. A., Kimberly, T. and Fuller, M. R. (1986). Developing a practical model to predict nesting habitat of woodland hawks. In Wildlife 2000, Modeling Habitat Relationships of Terrestrial Vertebrates (J. Verner and C. J. Ralph, eds), pp. 207-208. Wisconsin: University of Wisconsin Press.

Nudds, T. D. (1983). Niche dynamics and organization of waterfowl guilds in variable environments. Ecology 64, 319-330.

Prodon, R. (1976). Le substrat, facteur écologique et éthologique de la vie en eau courante: observations et expériences sur les larves de Microptera testacea et Cordulegaster annulatus. Unpublished 3e cycle thesis, University of Lyon $I$.

Rice, J. C., Ohmart, R. D. and Anderson, B. W. (1986). Limits in a data-rich modeling experience with habitat management on the Colorado river. In Wildlife 2000, Modeling Habitat Relationships of Terrestrial Vertebrates (J. Verner and C. J. Ralph, eds), pp. 79-86. Wisconsin: University of Wisconsin Press.

Ruger, A., Prentice, C. and Owen, M. (1986). Results of the IWRB International Waterfowl Census (19671983). Glos., U.K.: IWRB, Slimbridge.

Saint-Gérand, T. (1985). Bilan écologique de la distribution écologique des Anatidés et des Foulques hivernant en France. Gibier Faune Sauvage 1, 5-62.

Schamberger, M. L. and O'Neil, L. J. (1986). Concepts and constraints of habitat-model testing. In Wildife 2000, Modeling Habitat Relationships of Terrestrial Vertebrates (J. Verner and C. J. Ralph, eds), pp. 5-10. Wisconsin: University of Wisconsin Press.

Shugart, H. H. (1981). An overview of multivariate methods and their application to studies of wildlife habitat. In The Use of Multivariate Statistics in Studies of Wildlife Habitat (D. E. Capen, ed.), pp. 4-10. Fort Collins, Colorado: USDA Forest Service, Rocky Mountain Forest and Range Experiment Station.

Scott, D. A. (1980). A Preliminary Inventory of Wetland of International Importance of Waterfowl in West Europe and Northwest Africa. Glos., U.K.: IWRB, Slimbridge.

Straw, J. A., Wakeley, J. S. and Hudgins, J. E. (1986). A model of management of diurnal habitat for American woodcock in Pennsylvania. Journal of Wildlife Management 50, 378-383.

Tamisier, A. (1972). Etho-écologie des Sarcelles d'hiver (Anas c. crecca L.) pendant leur hivernage en Camargue. Unpublished state thesis, University of Montpellier.

Tamisier, A. (1974). Etho-ecological studies of teal wintering in the Camargue (Rhone Delta, France). Wildfow/ 25, 122-133.

Ter Braak, C. J. F, and Looman, C. W. N. (1986). Weighted averaging, logistic regression and the Gaussian response model. Vegetatio $65,3-11$.

Ter Braak, C. J. F. and Prentice, I. C. (1988). A theory of gradient analysis. Advances in Ecological Research 18 271-317. 
Tesson, J. L. (1988). Les zones humides à vocation agricole, situation présente et perspectives d'avenir. Bulletin Mensuel de l'ONC 126, 43-46.

Williams, B. K. (1981). Discriminant analysis in wildlife research: theory and applications. In The Use of Multivariate Statistics in Studies of Wildlife Habitat (D. E. Capen, ed.), pp. 59-71. Fort Collins, Colorado: USDA Forest Service, Rocky Mountain Forest and Range Experiment Station.

Yésou, P., Trollier, B. and South, M. (1983). Anatidés et zones humides de France métropolitaine. Bulletin Mensuel de l'ONC Spécial Scientifique et Technique. Paris: Office Nationale de la Chasse.

\section{Appendix 1.}

\section{LENGTH OF THE FIELD OF VIEW}

The longest line of view from the observation point $\mathrm{O}$ at a height $>1 \mathrm{~m}$ from the ground, is drawn (length $L$ ). The straight line perpendicular to it and passing through the observation point is then drawn [length $l$, Fig. 6(a)]. The mean length of the field of view is then estimated by $(L+l) / 4(\mathrm{~m})$.

\section{ANGLE OF VIEW}

A straight line (A) is drawn between the observation point and the furthest part of the field of view. A straight line (B) is then drawn perpendicular to it, as long as possible in the field of view and as far as possible from the observer. The angle a $\left(^{\circ}\right)$ is then drawn, as indicated on Fig. 6(b).
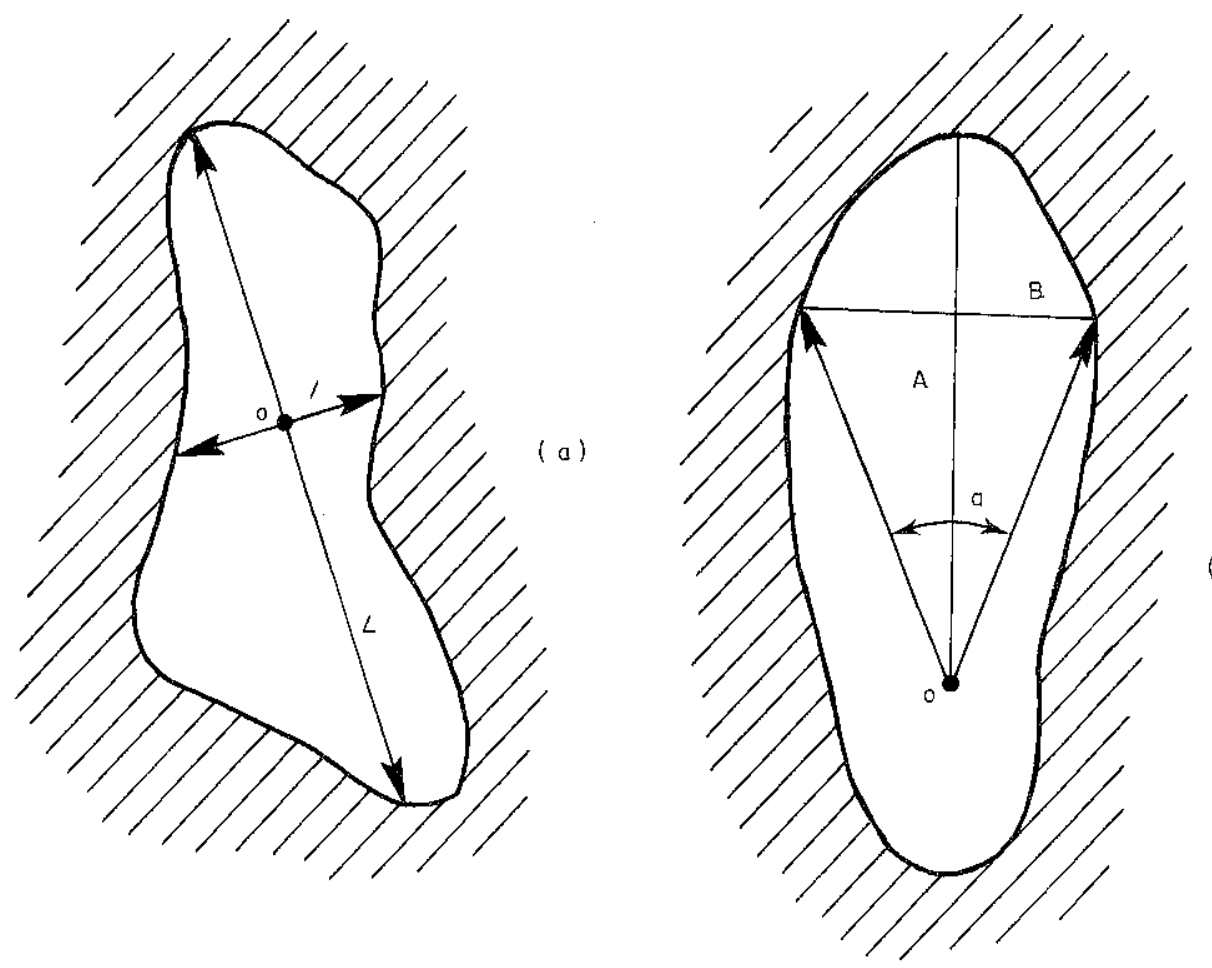

Figure 6. Measures of the length of the field of view (a) and of the angle of view (b). 


\section{Appendix 2.}

MODALITIES OF THE 20 VARIABLES MEASURED

Water $<0.2 \mathrm{~m}$ deep

(per cent cover)

D11: 0

D12: 0-25

D13: $25-50$

D14: $50-100$

Water $>0.4 \mathrm{~m}$ deep

(per cent cover)

D31: 0

D32: 0-25

D33: $25-50$

D34: $50-100$

Reed beds

(per cent cover)

RE1: 0

RE2: 0-25

RE3: $25-50$

RE4: $50-100$

Dry rushes

DR1: 0

DR2: 0-25

DR3: 25-100

Grasslands $>0.25 \mathrm{~m}$ high (per cent cover)

HG1: 0

HG2: 0-25

HG3: 25-100

Trees

(per cent cover)

T1: 0

T2: $0-25$

T3: $25-50$

T4: $50-100$

Medium sloping banks (per cent of bank length)

B21: 0

B22: 0-50

B23: $50-100$

Steep sloping banks (per cent of bank length)

B41: 0

B42: 0-50

B43: $50-100$
Water $0 \cdot 2-0 \cdot 4 \mathrm{~m}$ deep

(per cent cover)

D21: 0

D22: 0-25

D23: $25-50$

D24: $50-100$

Mud or gravel

(per cent cover)

MU1: 0

MU2: 0-25

MU3: 25-50

MU4: $50-100$

Flooded rushes

(per cent cover)

FR 1: 0

FR2: 0-25

FR3: 25-100

Grasslands $<0.25 \mathrm{~m}$ high

LG1: 0

LG2: 0-25

LG3: 25-50

LG4: $50-100$

Bushes

(per cent cover)

B1: 0

B2: $0-25$

B3: $25-50$

B4: $50-100$

Shallow sloping banks (per cent of bank length)

B11: 0

B12: 0-50

B13: $50-100$

Moderately steep sloping banks (per cent of bank length)

B31: 0

B32: 0-50

B33: $50-100$

Area of the pond

(ha)

WA1: 0

WA2: $0-2$

WA3: $2-10$

WA4: $>10$ 
Area of flooded rushes

(ha)

RA1: 0

RA2: $0-0 \cdot 5$

RA3: $>0.5$

Length of the field of view $(\mathrm{m})$

FW1: $<20$

FW2: $20-70$

FW3: 70-125

FW4: $>125$
Mean salinity

(\%)

MS1: 8

MS2: 12

MS3: 18

Angle of view

$\left({ }^{\circ}\right)$

AV1: $<3$

AV2: $3-15$

AV3: $15-45$

AV4: $>45$

Appendix 3. Calculation of the probability of occurrence of teal according to the position of sampling points on the axis of the discriminant barycentric analysis

Only points from $\mathrm{A}+\mathbf{B}$, the study area to be modelled, are considered here.

\section{PRESENTATION OF THE PROBLEM}

Let us consider a sample of $n$ points representative of the study area. If an environmental gradient exists, likely to be divided into intervals, $i$, the distribution of the points of the sample on the gradient, which has to be estimated, is:

Interval

Points with teal

Points without teal

Total

$$
\begin{array}{llllll}
1 & 2 & \ldots & i & \ldots & \text { Total } \\
n 1+ & n 2+ & \ldots & n i+ & \ldots & n F \\
n 1- & n 2- & \ldots & n i- & \ldots & n(1-F) \\
n 1 & n 2 & \ldots & n i & \ldots & n
\end{array}
$$

where $F$ is the mean probability of occurrence of teal in a sampling point of the study area ( $F$ is previously known).

We pose:

$$
n i+/ n i=P_{i} \text { and } \mathrm{ni}-/ \mathrm{ni}=1-P_{i} \text {, so } n i+/ n i-=P_{i} / 1-P_{i}
$$

$P_{i}$, the mean probability of occurrence of teal in interval $i$, has to be estimated.

ESTIMATION OF $P_{i}$

Let us consider two samples of NA and NB points, representative, respectively, of parts occupied and unoccupied by teals of the study area (NA can be equal to NB). A discriminant barycentric analysis is performed on these points described by habitat variables. The discriminant axis is divided into $i$ intervals. The distribution of the points along these intervals is:

Interval

Points with teal

Points without teal

Total

$\begin{array}{llllll}1 & 2 & \ldots & i & \ldots & \text { Total } \\ \text { NA1 } & \text { NA2 } & \ldots & \text { NA } i & \ldots & \text { NA } \\ \text { NB1 } & \text { NBS } & \ldots & \text { NB } i & \ldots & \text { NB } \\ \text { N1 } & \text { N2 } & \ldots & \text { Ni } & \ldots & \text { N }\end{array}$


Intervals are those previously noticed. NA and NB being large enough, the distribution of points with or without teal is the same as before. So we have:

$$
\begin{gathered}
\mathrm{NA} i / \mathrm{NA}=n i+/ n F \Rightarrow \mathrm{NA} i=n i+\times \mathrm{NA} / n F \\
\mathrm{NB} i / \mathrm{NB}=n i-/ n(1-F) \Rightarrow \mathrm{NB} i=n i-\times \mathrm{NB} / n(1-F)
\end{gathered}
$$

$(1),(2),(3) \Rightarrow \mathrm{A} i=\mathrm{NA} i / \mathrm{NB} i=(n i+/ n i-) \times(\mathrm{NA} / \mathrm{NB} \times(1-F / F)=$

$$
\left(P_{i} / 1-P_{i}\right) \times(\mathrm{NA} / \mathrm{NB}) \times(1-\mathrm{F} / \mathrm{F})(4)
$$

(4) $\Rightarrow P_{\mathrm{i}}=\mathrm{A} i \mathrm{FNB} /(\mathrm{A} i \mathrm{FNB}+(1-F) \mathrm{NA})$ 
